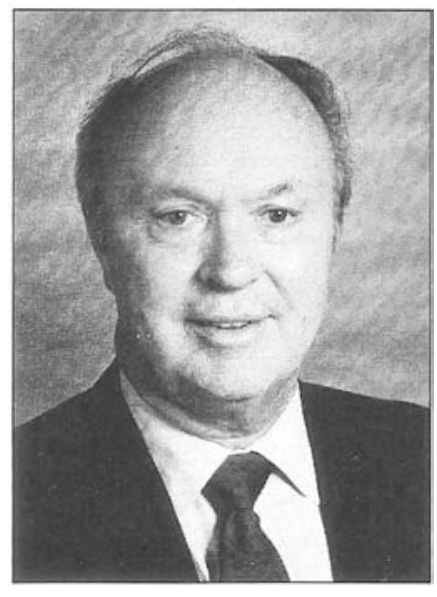

\author{
KENNETH R. FARRELL \\ Vice President \\ Agriculture and Natural Resources
}

\title{
Research and extension centers: vital link in the flow of knowledge
}

No state in the nation has a more diverse, well developed agricultural economy than does California, growing more than $250 \mathrm{com}$ modities from almonds to zucchini. Nor does any state face more complex technological problems in agriculture, natural resources, and the environment. To help find answers to these problems, the University of California maintains a diverse, sophisticated system of field research facilities.

An integral part of UC's Division of Agriculture and Natural Resources, the nine distinctive agricultural research and extension centers are strategically situated throughout the state. At one extreme is the Tulelake center, 4,000 feet high, on the Oregon border. In the chilly interior mountains, Tulelake can experience frost any month of the year. South by 700 miles, the Imperial Valley center sits below sea level near the Mexican border, where 120-degree temperatures are routine during the summer. The nine centers combined constitute a $\$ 6$ million program to help maintain the state's economic and environmental well-being.

Commonly known as "field stations," the system of research and extension centers provides a vital link in the flow of new knowledge from campus to commercial application.

Most of the basic agricultural research is conducted on the University's campuses at Berkeley, Davis, and Riverside. But some campus departments also station faculty at the centers. Other faculty, plus Cooperative Extension specialists from the three campuses, and county Cooperative Extension advisors, travel to the centers to conduct hundreds of applied research experiments each year. Through this lab-to-field linkage, basic research findings are tested, adapted, and applied to each region's unique soils, climate, and other ecological and production conditions. The result has been a steady flow of new information and technology to enhance agricultural productivity and management of natural resources for the benefit of farmers and Californians at large.

The centers are thus an integral, essential part of the UC research and extension system:

- Tulelake is in the town of the same name in Siskiyou County. It focuses on small grains, potatoes, and onions, important crops in the mountainous northeastern region. One of its creations is California's horseradish industry, the brainchild of a Tulelake researcher searching for a good cash crop for local farmers. The Tulelake center was the site for testing "ice minus," a genetically engineered bacterium developed at the UC Berkeley campus to enhance frost resistance in plants.

- Sierra Foothill, in the Sierra Nevada foothills near Browns Valley, is a center for research in cattle breeding, range management, and protection of the state's natural lands. The station is celebrating its 30th anniversary this year (see related articles in this issue).

- Hopland, 100 miles north of San Francisco, encompasses coastal foothills and valleys. Work focuses on sheep breeding, plus range improvement, watershed management, and wildlife enhancement, where the center's 5,300 acres allow large-scale natural resource research to be conducted.

- Deciduous Fruit center in San Jose, at age 70, is in a highly populous, urban area. Its 17 acres are surrounded by concentrated commercial development that overwhelmed virtually all of its agricultural neighbors. Yet important work at the center is still conducted in fruits, flowers, vegetables, and strawberries.

- West Side, one of three San Joaquin Valley stations, is noted for cotton research, along with studies in fruit, vegetables, and nut crops. Work at West Side has led to advances in drip irrigation and salinity management, with important findings for growers in the region.

- Kearney, 20 miles southeast of Fresno in Parlier, is the home of numerous varieties of table and wine grapes, tree fruits, including dwarf varieties, and many rare crops. Last year the University dedicated a $\$ 5$ million research building at Kearney. It is our largest off-campus research facility, with 25 permanent academic research staff. Now funds are being raised for a postharvest research building that offers the promise of important benefits to agriculture. - Lindcove, a few miles east of Exeter, is situated on the first rise of Sierra slopes from the San Joaquin Valley. Lindcove plays an essential role in citrus research. On its grounds is maintained the Citrus Clonal Protection Program, a priceless repository of more than 400 carefully selected parent trees that form the basis for much of California's citrus industry.

- South Coast, near Santa Ana, is a leading site for citrus, and pest and disease management research. The center is the home of many of the new high-yielding strawberry varieties released by the University. Landscape, turfgrass, and ornamentals are other important research foci of the center.

- Imperial Valley, near El Centro, is the University's low desert research site. Established in 1911, it is California's oldest station still in use. Vegetable and grain crops are important research concerns, along with cattle management and irrigation. Last December the University dedicated a new research and office building for Imperial County Cooperative Extension staff at the center.

With a diversity that matches California's own, the agricultural research and extension centers play an important role in the state's prosperity. As we move into the 21 st century, the economic and environmental concerns facing agriculture are enormous and complicated. New knowledge holds the key to dealing with most of those problems. The centers will continue to contribute to development of that knowledge through their unique and irreplaceable role in the University of California's research-extension continuum. 